\title{
OPTIMIZATION OF THE SYSTEM OF IRRIGATED WINTER WHEAT PROTECTION AGAINST HARMFUL ORGANISMS IN SOUTHERN UKRAINE
}

\author{
O. Y. MARKOVSKA, Ph.D. in agriculture, Senior Researcher \\ Kherson State Agricultural University \\ E-mail:mark.elena@ukr.net \\ M.Y. PIKOVSKYI, Ph.D. in biology \\ E-mail:mprmir@ukr.net
}

National University of Life and Environmental Sciences of Ukraine

O. O. NIKISHOV, postgraduate student, department of agrotechnologies Institute of Irrigated Agriculture of NAAS

https://doi.org/10.31548/bio2018.03.012

The research findings show that the highest effectiveness in irrigated winter wheat protection against harmful organisms is provided with the application of seed disinfectant Serticor 050 FS (1 1/t), fungicide Alto Super 330 EC, emulsion concentrate, together with herbicide Peak $75 \%$ water-soluble granules $(0.45 \mathrm{l} / \mathrm{ha}+0.020 \mathrm{~kg} / \mathrm{ha})$ in the $\mathrm{stem}$ elongation phase, as well as fungicide Amistar Extra $280 \mathrm{SC}$ suspension concentrate $(0.5 \mathrm{l} / \mathrm{ha})$ at the beginning of flowering, and insecticide Enzhio, $24.7 \%$ suspension concentrate $(0.181 / \mathrm{ha})$ at the beginning of milky ripeness of grain.

The study determined that Konka variety had a seed yield of $3.59 \mathrm{t} / \mathrm{ha}$, which is $8.2 \%$ more than in Khersonska 99. The combined application of biopreparations Trichodermin and Gaupsin proved to be the most effective. Avatar had an advantage over other micronutrients under study and allowed gaining a 7.3-14.2\% seed yield increase. Dispersion analysis confirms that microfertilizers take up the greatest proportion (58.2\%) in the impact on the formation of winter wheat yield. The effect of varietal composition $(\mathbf{2 0 . 0} \%)$ and plant protection (16.1\%) was also high.

Ключові слова: winter wheat, diseases, harmful organisms, weeds, preparations, effectiveness

Introduction. Winter wheat is the main food crop grown in all soil and climatic zones of Ukraine. Harmful organisms are among the many factors that affect its yield. Under the steppe conditions, smut diseases, root rot, powdery mildew, septoriosis, orange leaf rust, various types of weeds, cereal aphids, wheat thrips, chinch bugs and others are hazardous. They lead to a significant loss of crop yield and cause deterioration in its quality [3].
Considering the foregoing, there is a need to study the effectiveness of comprehensive measures for the protection of winter wheat crops against diseases, pests and weeds.

Analysis of recent research findings and publications. In many countries of the world, various aspects of winter wheat protection against harmful organisms are being investigated. In Ukraine, in particular, the application of herbicides Estrone, Grantar gold, Esteron + Puma super provided the highest 
technical efficacy for different biogroups of weeds [4, p. 119]. The spraying of crops in the phase of milky ripeness of grain with pyrethroid insecticide Karate Zeon 050 CS, microencapsulated suspension, is an effective method of chemical protection of winter wheat against suctorial pests [5, p. 149].

At the same time, the possibility of using an integrated program of wheat protection from harmful organisms is shown under the conditions of Poland [6, p. 226]. In Serbia (in semi-arid regions), a study was conducted on integrated wheat protection against the most common fungal diseases [7, p. 1].

The aim of research is to study the efficacy of chemical pesticides and biopreparations combined with microfertilizers in their complex application against harmful organisms of winter wheat.

Research methods. The research was carried out on the test field of the Institute of Irrigated Agriculture of the National Academy of Agrarian Sciences of Ukraine in 2008-2016. The soil of experimental sites is dark chestnut medium-sandy weakly salined; it is characterized by a well-developed soil profile; humus content in the $0-30 \mathrm{~cm}$ soil layer is $2.1 \%$, total nitrogen makes up $0.18 \%$, the content of phosphorus is $0.16 \%$, the soil also has an increased potassium content of $2.6 \%$.

Diagnosis of diseases and identification of harmful organisms were carried out according to the methods provided in a number of publications $[1,8]$. Generally accepted techniques were used to perform field studies [2].

Results and discussion. The research results show that presowing treatment of seeds with desinfectants contributed to increased germinating power, growth intensity, even stands and a significant reduction in the spread and development of fungul diseases. So, the infestation of smut diseases in Lamardor 400 FS and Serticor 050 FS variants decreased by $100 \%$, that of fusarial and helminthosporious root rot by 78.3; 82.3 and $80.2 ; 84.0 \%$, respectively (Table 1 ).

The efficacy of Vitavaks $200 \mathrm{FF}$ in the control of smut diseases and root rot is lower than in the variants with Lamardor $400 \mathrm{FS}$ and Serticor 050 FS.

Throughout the years of research, shepherd's purse (Capsella bursa pastoris L.) and tansy mustard (Descurania Sophia L.) dominated in the species composition of weeds on the experimental field of irrigated winter wheat, at 46.3 and $25.6 \%$, respectively The weediness of

\section{Effectiveness of seed disinfectants for Khersonska Awnless winter wheat variety (average for 2009-2011)}

\begin{tabular}{|c|c|c|c|c|c|c|c|}
\hline \multirow{3}{*}{$\begin{array}{l}\text { Seed } \\
\text { disinfectant }\end{array}$} & \multirow{3}{*}{$\begin{array}{c}\text { Disinfec- } \\
\text { tant } \\
\text { applica- } \\
\text { tion rate, } \\
1 / \mathrm{t} \\
\end{array}$} & \multirow{3}{*}{$\begin{array}{c}\text { Growth } \\
\text { intensity, } \\
\%\end{array}$} & \multirow{3}{*}{$\begin{array}{l}\text { Laborato- } \\
\text { ry germi- } \\
\text { nation, } \\
\%\end{array}$} & \multicolumn{4}{|c|}{ Effectiveness, $\%$} \\
\hline & & & & \multirow{2}{*}{$\begin{array}{l}\text { bunt of } \\
\text { wheat }\end{array}$} & \multirow[b]{2}{*}{$\begin{array}{l}\text { loose } \\
\text { smut }\end{array}$} & \multicolumn{2}{|c|}{ root rot } \\
\hline & & & & & & fusarial & $\begin{array}{l}\text { helmintho- } \\
\text { sporious }\end{array}$ \\
\hline $\begin{array}{l}\text { Control (without } \\
\text { treatment) }\end{array}$ & - & 83.0 & 88.5 & - & - & - & - \\
\hline $\begin{array}{l}\text { Lamardor } 400 \mathrm{FS} \text {, } \\
\text { flowable suspen- } \\
\text { sion concentrate }\end{array}$ & 0.15 & 86.9 & 93.2 & 100.0 & 100.0 & 78.3 & 82.3 \\
\hline $\begin{array}{l}\text { Serticor } 050 \mathrm{FS} \text {, } \\
\text { suspension con- } \\
\text { centrate }\end{array}$ & 1.0 & 87.4 & 93.8 & 100.0 & 100.0 & 80.2 & 84.0 \\
\hline $\begin{array}{l}\text { Vitavaks } 200 \mathrm{FF} \text {, } \\
\text { water suspension } \\
\text { concentrate }\end{array}$ & 2.5 & 85.8 & 91.4 & 98.7 & 99.2 & 74.8 & 80.2 \\
\hline
\end{tabular}


crops with creeping thistle (Cirsium arvense L.) and common ragweed (Ambrozia artemiziifolia L.) was $9.8 \%$ and $14.3 \%$, respectively. Other weeds made up $4.0 \%$.

We experimentally studied herbicides Granstar 75\%, water-soluble granules, Peak $75 \%$, water-soluble granules, Grodil Maxi $37.5 \%$, oil dispersion. They were applied in combination with a fungicide at the stem elongation stage. The number of weeds after 30 days after chemical treatment was 4.6-10.2 times lower, whereas in the control it increased by $6.3 \%$ (Table 2 ).

The results of the experiment indicate that herbicide Grodil Maxi 37.5\%, oil dispersion, was the most effective on experimental plots of winter wheat, which contributed to a decrease in weediness by $98.5-99.0 \%$. In this case, we achieve effective control of such types of weeds as creeping thistle, tansy mustard, shepherd's purse and common ragweed.

In variants with the application of herbicides Granstar 75\%, water-soluble granules, and Peak $75 \%$, water-soluble granules, the effectiveness of protection was practically the same (95.2-97.2\%).

During autumn vegetation of spike cereals, phytophags (cereal flies, cicadas, aphids) did not have economic importance. The numbers of spring generation of cereal flies were lower than the economic threshold of harmfulness (ETH). The greatest threat to winter wheat crops in the years of research was created by chinch bugs and wheat thrips. In the phase of milky ripeness of wheat, the number of their larvae was 7.8-8.5 specimens $/ \mathrm{m}^{2}$ and 11.7-15.2 specimens per ear, respectively. The population of greenbugs (common and barley aphids) on plants varied from 3.2 to 9.0 specimens / stem.

The protection of experimental plots from a complex of suctorial pests was carried out at the beginning of the milky ripeness of grain. Spraying winter wheat with insecticides Fastak, 10\% emulsion concentrate, Enzhio, $24.7 \%$ suspension concentrate, and Detsis Profi, 25\%, water-soluble granules, following the recommended application rates, reduced the number of bugs by $93.8-98.7 \%$, that of wheat thrips and cereal aphids by 94.6-98.9 and $92.5-98,3 \%$, respectively (Fig. 1).

The research results show that Enzhio, $24.7 \%$, suspension concentrate, applied at a rate of $0.18 \mathrm{l} /$ ha displayed higher efficacy against all species of suctorial phytophages.

Throughout the years of research, autumn occurrence of fungal diseases in irrigated winter wheat had no economic significance. In the spring-summer period, powdery mildew, septoriosis and orange leaf rust were a threat, which caused a need for fungicides applica-

\section{Effect of herbicides on a decrease in the weediness of winter wheat (Khersonska} Awnless variety, average for 2008-2010)

\begin{tabular}{|c|c|c|c|c|c|}
\hline \multirow[b]{2}{*}{ No. } & \multirow[b]{2}{*}{ Variant } & \multicolumn{3}{|c|}{ weediness, $\mathrm{pcs} / \mathrm{m}^{2}$} & \multirow{2}{*}{$\begin{array}{c}\% \text { of } \\
\text { decrease } \\
\text { compared to } \\
\text { control }\end{array}$} \\
\hline & & $\begin{array}{l}\text { before chem- } \\
\text { ical treat- } \\
\text { ment }\end{array}$ & $\begin{array}{c}30 \text { days after } \\
\text { treatment }\end{array}$ & $\begin{array}{l}\text { before har- } \\
\text { vesting }\end{array}$ & \\
\hline 1. & Control (no herbicide) & 39.8 & 42.3 & 42.0 & - \\
\hline 2. & \multirow{2}{*}{$\begin{array}{l}\text { Granstar } 75 \% \text {, water-soluble } \\
\text { granules, } 0.02 \mathrm{~kg} / \mathrm{ha}\end{array}$} & 40.3 & 6.5 & 1.5 & 96.3 \\
\hline 3. & & 38.7 & 5.2 & 1.4 & 95.2 \\
\hline 4. & \multirow{2}{*}{$\begin{array}{l}\text { Peak } 75 \% \text {, water-soluble } \\
\text { granules, } 0.02 \mathrm{~kg} / \mathrm{ha}\end{array}$} & 40.8 & 4.5 & 0.9 & 96.7 \\
\hline 5. & & 38.5 & 3.8 & 0.9 & 97.2 \\
\hline 6. & \multirow{2}{*}{$\begin{array}{l}\text { Grodil Maxi } 37.5 \% \text {, oil } \\
\text { dispersion, } 0.11 / \text { ha }\end{array}$} & 39.3 & 8.1 & 0.6 & 98.5 \\
\hline 7. & & 37.9 & 8.2 & 0.5 & 99.0 \\
\hline \multicolumn{2}{|c|}{$\begin{array}{l}\text { Least significant difference (LSD) } \\
05, \mathrm{pcs} / \mathrm{m}^{2}\end{array}$} & 3.12 & 3.82 & 2.95 & \\
\hline
\end{tabular}




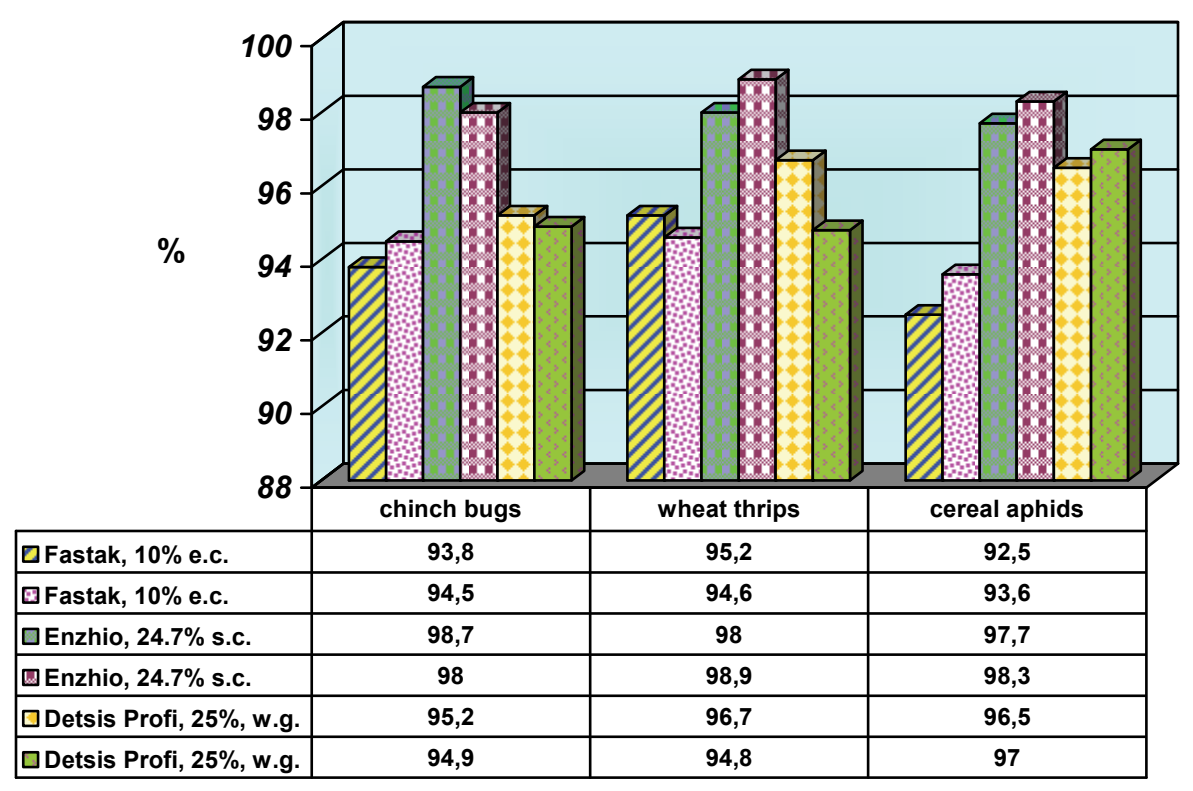

Fig. 1. Effectiveness of insecticides against suctorial pests of winter wheat (Khersonska Awnless variety, average for 2008-2010)

tion. The first treatment with fungicides was carried out at the stem elongation stage, together with herbicides; the second one was provided at the beginning of flowering.

The fungicides applied contributed to a significant improvement in the phytosanitary state of winter wheat throughout the entire growing season. Of the studied fungicides, the best were Amistar Extra 280 3C, suspension concentrate, Falcon, 46\% suspension concentrate, Impact, 25\% emulsion concentrate (Table 3).

Peak effectiveness of protection against the complex of fungal diseases was reached in variants of double application of fungicides in the phase of stem elongation and at the beginning of flowering of winter wheat, which reduced the development of powdery mildew by $93.2-97.9 \%$, that of septoriosis by $89.0-98.0$; and that of orange leaf rust by $93.8-98.3 \%$.

It was established that the agrotechnical factors investigated (plant protection and microfertilizers) significantly influenced seed productivity in Khersonska 99 and Konka varieties (Table 4).
The study proves that Konka variety formed an average yield of seeds at the level of $3.59 \mathrm{t} / \mathrm{ha}$, and in Khersonska 99 this indicator was $3.32 \mathrm{t} / \mathrm{ha}$, i.e. $8.2 \%$ less.

The use of chemical and biological protection had a varying effect on seed yield of the test crop. Here, we got an average of 3.27 $\mathrm{t}$ / ha of winter wheat seeds by factor B under traditional fungicidal protection.

The application of Gaupsin allowed increasing this indicator by $6.7 \%$, while the combined use of biopreparations Trichodermin and Gaupsin helped to form the maximum seed yield of $(3.65 \mathrm{t} / \mathrm{ha})$, which is $6.7-11.6 \%$ more than in other variants studied.

The application of microelements resulted in an increase in seed productivity of the studied crop from $3.08 \mathrm{t} /$ ha in the control to 3.35-3.82 $\mathrm{t} / \mathrm{ha}$ on the plots treated with Riverm, Nanovit Micro and Avatar. So, the use of these preparations contributed to a significant increase in seed yield - by 8.7$24.1 \%$. Avatar had an advantage over other micronutrients under study: it allowed obtain- 


\section{Effectiveness of fungicides against fungal diseases of winter wheat (Khersonska} Awnless variety, average for 2008-2010)

\begin{tabular}{|c|c|c|c|c|c|c|}
\hline \multirow[b]{2}{*}{ No. } & \multirow[b]{2}{*}{ Fungicide } & \multirow{2}{*}{$\begin{array}{c}\text { Application } \\
\text { rate, l; kg/ } \\
\text { ha }\end{array}$} & \multirow[b]{2}{*}{$\begin{array}{c}\text { Development } \\
\text { stage of the crop }\end{array}$} & \multicolumn{3}{|c|}{ Effectiveness, \% } \\
\hline & & & & $\begin{array}{l}\text { powdery } \\
\text { mildew }\end{array}$ & $\begin{array}{l}\text { leaf septo- } \\
\text { riosis }\end{array}$ & $\begin{array}{c}\text { orange } \\
\text { leaf rust }\end{array}$ \\
\hline 1. & $\begin{array}{c}\text { Control } \\
\text { (no protection) }\end{array}$ & - & - & - & - & - \\
\hline 2. & $\begin{array}{c}\text { Bileton, } 25 \% \text { wettable } \\
\text { powder }\end{array}$ & 0.5 & stem elongation & 85.0 & 64.9 & 70.2 \\
\hline \multirow[t]{2}{*}{3.} & $\begin{array}{c}\text { Bileton, } 25 \% \text { wettable } \\
\text { powder }\end{array}$ & 0.5 & stem elongation & \multirow{2}{*}{93.2} & \multirow{2}{*}{86.0} & \multirow{2}{*}{93.8} \\
\hline & $\begin{array}{c}\text { Impact, } 25 \% \text { emulsion } \\
\text { concentrate }\end{array}$ & 0.5 & $\begin{array}{l}\text { beginning of flow- } \\
\text { ering }\end{array}$ & & & \\
\hline 4. & $\begin{array}{l}\text { Alto super } 330 \mathrm{EC} \text {, } \\
\text { emulsion concentrate }\end{array}$ & 0.45 & stem elongation & 87.0 & 86.2 & 84.0 \\
\hline \multirow[b]{2}{*}{5.} & \multirow{2}{*}{$\begin{array}{c}\text { Alto super } 330 \mathrm{EC}, \\
\text { emulsion concentrate } \\
\text { Amistar Extra } 280 \text { 3C, } \\
\text { suspension concen- } \\
\text { trate }\end{array}$} & 0.45 & stem elongation & \multirow[b]{2}{*}{97.9} & \multirow[b]{2}{*}{98.3} & \multirow[b]{2}{*}{98.3} \\
\hline & & 0.5 & $\begin{array}{l}\text { beginning of flow- } \\
\text { ering }\end{array}$ & & & \\
\hline 6. & $\begin{array}{c}\text { Falcon, } \\
46 \% \text { suspension con- } \\
\text { centrate } \\
\end{array}$ & 0.6 & stem elongation & 85.9 & 83.5 & 84.9 \\
\hline \multirow[b]{2}{*}{7.} & $\begin{array}{c}\text { Falcon, } \\
46 \% \text { suspension con- } \\
\text { centrate }\end{array}$ & 0.6 & stem elongation & \multirow{2}{*}{97.2} & \multirow{2}{*}{98.0} & \multirow{2}{*}{97.0} \\
\hline & $\begin{array}{c}\text { Amistar Extra } 280 \text { 3C, } \\
\text { suspension concen- } \\
\text { trate }\end{array}$ & 0.5 & $\begin{array}{l}\text { beginning of flow- } \\
\text { ering }\end{array}$ & & & \\
\hline
\end{tabular}

4. Seed yield of winter wheat depending on varietal composition, plant protection and microelements, $t$ /ha (average for 2014-2016)

\begin{tabular}{|c|c|c|c|c|c|c|c|c|}
\hline \multirow[b]{2}{*}{ 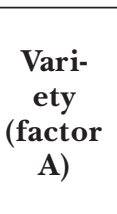 } & \multirow[b]{2}{*}{$\begin{array}{l}\text { Plant protec- } \\
\text { tion (factor B) }\end{array}$} & \multicolumn{5}{|c|}{ Microelements (factor $\mathbf{C}$ ) } & \multicolumn{2}{|c|}{$\begin{array}{l}\text { Average } \\
\text { by factors }\end{array}$} \\
\hline & & 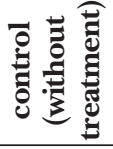 & $\begin{array}{l}\text { Riv- } \\
\text { erm }\end{array}$ & $\begin{array}{l}\text { Nano- } \\
\text { vit } \\
\text { Micro }\end{array}$ & Avatar & $\begin{array}{l}\text { aver- } \\
\text { age }\end{array}$ & $\mathbf{A}$ & B \\
\hline \multirow{3}{*}{$\begin{array}{c}\text { Kher- } \\
\text { sonska } \\
99\end{array}$} & Fungicide & 2.81 & 3.02 & 3.24 & 3.56 & 3.16 & \multirow{3}{*}{3.32} & 3.27 \\
\hline & Gaupsin & 2.89 & 3.21 & 3.38 & 3.60 & 3.27 & & 3.42 \\
\hline & $\begin{array}{l}\text { Trichodermin+ } \\
\text { Gaupsin }\end{array}$ & 3.13 & 3.40 & 3.67 & 3.87 & 3.52 & & 3.65 \\
\hline \multirow{3}{*}{ Konka } & Fungicide & 3.01 & 3.25 & 3.48 & 3.82 & 3.39 & \multirow{3}{*}{3.59} & \\
\hline & Gaupsin & 3.21 & 3.50 & 3.68 & 3.93 & 3.58 & & \\
\hline & $\begin{array}{c}\text { Trichodermin + } \\
\text { Gaupsin }\end{array}$ & 3.42 & 3.69 & 3.90 & 4.14 & 3.79 & & \\
\hline \multicolumn{2}{|c|}{ Average by factorC } & 3.08 & 3.35 & 3.56 & 3.82 & 3.45 & & \\
\hline
\end{tabular}




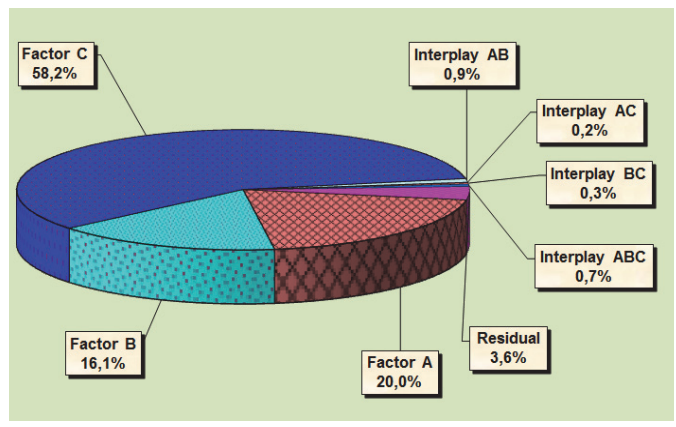

Fig. 2. Share of the impact of varietal composition (factor A), plant protection (factor B) and microfertilizers (factor C) on grain yield formation in winter wheat, $\%$ (average for 2014-2016).

ing $7.3-14.2 \%$ more seeds than under the application of Riverm and Nanovit Micro.

Dispersion analysis has shown that on the average, over three years of research, the influence of varietal composition, application of plant protection products and microfertilizers manifested itself unevenly (Figure 2).

Calculations testify that microfertilizers (factor C) had the greatest impact on the seed yield of the investigated crop (58.2\%). Varietal composition (factor A) was the second (20.0\%).

Chemical and biological means of plant protection (factor B) also significantly influenced the productivity of plants $(16.1 \%)$. The interaction of the factors was low, which could be explained by different reactions of plants to the investigated plant protection agents and microfertilizers; the residual effect of unrecognized factors, mainly weath- er conditions and differences in cultivation technology elements, was $3.6 \%$.

Conclusion and prospects for further research. The research findings show that the application of seed disinfectant Serticor $050 \mathrm{FS}(1 \mathrm{l} / \mathrm{t})$, fungicide Alto Super $330 \mathrm{EC}$, emulsion concentrate, together with herbicide Peak $75 \%$ water-soluble granules $(0.45$ $\mathrm{l} / \mathrm{ha}+0.020 \mathrm{~kg} / \mathrm{ha})$ in the stem elongation phase, and fungicide Amistar Extra 280 SC, suspension concentrate $(0.5 \mathrm{l} / \mathrm{ha})$ at the beginning of flowering, as well as the use of insecticide Enzhio, 24.7\% suspension concentrate $(0.18 \mathrm{l} / \mathrm{ha})$ at the beginning of milky ripeness of grain have provided the highest effectiveness in irrigated winter wheat protection against harmful organisms. Winter wheat variety Konka formed a seed yield of $3.59 \mathrm{t} / \mathrm{ha}$, which is $8.2 \%$ more than in Khersonska 99. The use of chemical and biological protection unevenly affected the seed productivity of the examined crop, the combined application of biopreparations Trichodermin and Gaupsin being the most effective. Avatar had an advantage over other micronutrients under study: it allowed obtaining 7.3-14.2\% more seeds than under the application of other preparations. Dispersion analysis determined that microfertilizers take up the greatest proportion $(58.2 \%)$ in the impact on winter wheat yield formation. The influence of varietal composition $(20.0 \%)$ and plant protection $(16.1 \%)$ was also high.

\section{References}

1. Veselovskyi, I.V., Lysenko, A.K., Manko, Yu. P. (1988). Atlas-vyznachnyk burianiv [Weed atlas] Kyiv, Urozhai, 128.

2. Metodyky vyprobuvannia i zastosuvannia pestytsydi. (2001). S.O. Trybel', D.D. Sihar'ova, M.P. Sekun, O.O. Ivashchenko ta in. [Methods of testing and application of pesticides] Kyiv, Svit, 447.

3. Stratehichni kultury. (2012). S.O. Trybel', S.V. Ret'man, O.I. Borzykh O.O. Stryhun. [Strategic cultures]. Kyiv, Kolobih, 368.

4. Tkalich, Yu. I., Matiukha, V. L., Bokun, O. I. (2014). Zakhyst posiviv ozymoi pshenytsi vid buraniv na chornozemakh zvychainykh pivnichnoho Stepu Ukrainy [Protection of winter wheat crops against weeds on ordinary chernozems of the northern steppes of Ukraine]. Naukovi pratsi Instytutu bioenerhetychnykh kultur i tsukrovykh burakiv, 20, 116-120. 
5. Shakhova, N. M., Kotsiurubenko, N. I. (2012). Zakhyst ozymoi pshenytsi vid sysnykh shkidnykiv. [Protection of winter wheat from suctorial pests]. Naukovi pratsi [Chornomorskoho derzhavnoho universytetu imeni Petra Mohyly kompleksu "Kyievo-Mohylianska akademiia". Seriia ekolohiia], $179,(167), 146-150$.

6. Jańczak, C., Pruszyński, S., Bubniewicz, P. (2002). Winter Wheat Protection against Diseases and Pests in Conventional Programme of Crop Protection and in Integrated Pest Management. Plant Protection Science, 38 (1), 221-226.

7. Jerkovic, Z.J., Jevtic, R.M., Lalosevic, M.S., Prijic, Z.S. (2013). Integrated protection from prevalent wheat parasites in semiarid region. Journal of Agricultural Sciences, 58 (1), 1-18.

8. Prescott, J.M., Burnett, P.A., Saari, E.E. et al. (1986). Wheat diseases and Pests. A guide to field identification. CIMMYT Mexico, 135.

\section{АНОТАЦІЯ}

О. Є. Марковсъка, М. Й. Піковсъкий, О. О. Нікішов. Оптимізаиія системи захисту пшенииі озимої від шкідливих організмів на зрошенні в умовах півдня Украӥни // Біоресурси $i$ природокористування. - 2018. - 10, №3-4. C.98-104. https://doi.org/10.31548/ bio2018.03.012

За результатами досліджень встановлено, шо найвишу ефективність дї у захисті пшенииі ози мої від шкідливих організмів за умов зрошення забезпечило застосування протруйника Сертікор $050 \mathrm{FS}(1 \mathrm{l} / \mathrm{m})$, фунгіииду Aльто Супер $330 \mathrm{EC}$, к.е. разом із гербіиидом Пік $75 \%$ в.г. $(0,45 \Omega / \imath a+0,020$ кг/га) у фазу виходу в трубку, а також фунгіииду Амістар Екстра 280 SC к.с. $(0,5 \pi /$ га) на початку ивітіння культури та інсектиииду Енжіо, 24,7\% к.c. $(0,18 \Omega / г а)$ - на початку молочної стиглості зерна. Визначено, шо сорт Конка мав врожайність насіння на рівні $3,59 \mathrm{~m} / 2$, шо на 8,2\% більше за сорт Херсонсъка 99. Iз біопрепаратів ефективним виявилося сумісне застосування Триходерміну та Гаупсину. Серед досліджуваних мікроелементів перевагу мав препарат Аватар, який забезпечував прибавку насіння в межах 7,314,2\%. Дисперсійним аналізом доведено, шо найбільша частка впливу формування врожаю пшенииі озимої належить мікродобривам (58,2\%). Також високим був вплив сортового складу $(20,0 \%)$ та захисту рослин (16,1\%).

Ключові слова: пшениия озима, хвороби, шкідники, бур'яни, препарати, ефективність дї

\section{АННОТАЦИЯ}

E. Е. Марковская, М. И. Пиковский, A. А. Никишов. Оптимизаиия системь зашиты пшеницы озимой от вредных организмов на орошении в условиях юга Украины // Биоресурсы и природопользование. - 2018. - 10, №3-4. C.98-104. https://doi.org/10.31548/ bio2018.03.012

По результатам исследований установлено, что наибольшую эффективность действия в зашите пшенииы озимой от вредных организмов в условиях орошения обеспечило использование протравителя Сертикор 050 FS (1л/m), фунгииида Альто Супер 330 EC, к.э. вместе с гербииидом Пик $75 \%$ в.г. $(0,45$

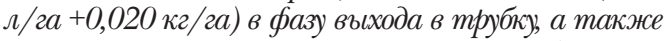
фунгииида Амистар Экстра 280 SC к.с. $(0,5 \Omega /$ га) в начале иветения культуры и инсектииида Энжио, $24,7 \%$ к.с. $(0,18$ л/га) - в начале молочной спелости зерна. Ооределено, что сорт Конка имел урожайность зерна на уровне 3,59 m/га, что на 8,2\% боль ше, чем у сорта Херсонская 99. Из биотрепаратов эффективным оказалось совместное применение Триходермина и Гаупсина. Среди исследуемъхх микроәлементов преимушество имел препарат Аватар, который обеспечил прибавку урожал зерна в пределах 7,3-14,2\%. Дисперсионным анализом доказано, ито наибольшая часть влияния на формирование урожая пшенииы озимой принадлежит микроудобрени ям (58,2\%). Также высоким было влияние сортового состава (20\%) и зашиты растений (16,1\%).

Ключевые слова: пиенииа озимая, болезни, вредители, сорняки, препараты, эффективность действия 